\title{
NUMBER OF CUTS FOR ESTIMATING FORAGE PRODUCTIVITY IN
} Panicum maximum

\author{
NÚMERO DE CORTES PARA ESTIMATIVA DA PRODUTIVIDADE DE FORRAGEM \\ EM Panicumm maximum
}

\section{Francisco Eduardo TORRES'; Paulo Eduardo TEODORO², Simone Botelho BENITES², Elisa Fidêncio de OLIVEIRA ${ }^{3}$, Caio Cezar Guedes Corrêa ${ }^{2}$, Flávia Alves da SILVA ${ }^{2}$}

1. Engenheiro Agrônomo, Professor, Doutor, Universidade Estadual de Mato Grosso do Sul - UEMS/UUA, Aquidauana, MS, Brasil; 2. Discentes do Programa de Pós-Graduação stricto sensu em Agronomia - área de concentração: Produção Vegetal - UEMS, Aquidauana, MS, Brasil. eduteodoro@ hotmail.com; 3. Discente do Programa de Pós-Graduação stricto sensu em Agronomia - área de concentração: Produção Vegetal da Universidade Estadual Paulista “Julio de Mesquita Filho" - UNESP, Botucatu, MS, Brasil.

\begin{abstract}
The evaluation of the coefficient of repeatability (r) allows verify if the superiority or initial inferiority of an individual remains over the measurements, being important for genetic breading programs with forages. Thus, this research aimed to determine the minimum number of cuts for selection with greater efficiency and reliability and to phenotypic stabilization of $P$. maximum cultivars. The experiment was conducted during the months of September 2011 to October 2012 at the State University of Mato Grosso do Sul. It were used three P. maximum cultivars (Massai, Mombaça and Tanzânia) for evaluation of dry mass of leaves and stems and total dry mass in six cuts. From this cuts, it was estimated the coefficient of $\mathrm{r}$ repeatability by methods ANOVA, principal components (correlation and covariance matrices) and structural analysis, as well as the required number of cuts based on pre-established coefficients of determination $(0.80,0.85,0.90,0.95$ and 0.99$)$. Seven harvests are necessary to discriminate with $85 \%$ accuracy in $P$. maximum cultivars based on the traits dry mass of leaves, dry mass of stems and total dry mass. The exclusion of the first three harvests promotes increase in coefficients of repeatability and determination due to forage production stabilization of $P$. maximum cultivars.
\end{abstract}

KEYWORDS: Reliability. Experimental precision. Repeatability.

\section{INTRODUCTION}

The area occupied by the species Panicum maximum Jacq. corresponds to approximately $20 \%$ of the pasture cultivated area in Brazil (around 100 million hectares) supplying $30 \%$ of the forage seed market. Considering the increasing intensification of cattle production systems in Brazil, this species, by its productive potential and its quality, is one of the most suited to this type of exploration (OLIVEIRA et al., 2014). The availability of improved cultivars such as Tanzania, Mombasa and Massai, have been responsible for the expansion of cultivation area of this forage (TORRES et al, 2013, 2015b). The continuation of genetic breeding researches of this forage will contribute significantly to the increase of meat, milk, leather and wool production in the country (MARTUSCELLO et al., 2007).

In breeding programs with forages is common the assessment of the traits as dry mass of leaves, dry mass of stems and total dry mass (TORRES et al, 2013). These traits are used for the identification of $P$. maximum genotypes better adapted to a particular environment in order to measure the behavior of the major phenotypic traits. However, one of the difficulties with the selection of forage genotypes genetically superior concerns the determination of the number of measurements (cuts) required for estimating the differences between genotypic materials (CARGNELUTTI FILHO et al., 2004).

During the process of selection of genotypes with a view to launching cultivars or parental choice for recombination, it is important to make sure, the genetic superiority of individuals. To this end, are often carried out repeated measurements in the same individual (NEGREIROS et al., 2008). Therefore, determining the number of measurements to be performed by repeatability coefficient it is necessary to perennial species because it provides an approximation of the maximum value that the heritability of a trait, in the broad sense, can achieve (CRUZ et al., 2014). In addition, this information is valuable for breeding programs, since it allows estimating what the lowest possible selection cycle and allocating human and financial resources to the research (TORRES et al, 2015).

The evaluation of the coefficient of repeatability ( $r$ ) allows verify if the superiority or initial inferiority of an individual remains over the measurements. High values of $r$ for any characteristics indicate that it is possible to predict the true value of the individuals based on a certain number of measurements. Thus, the consistency 
measure of position relative to the classification of individuals over successive measurements of a given trait is named repeatability (CRUZ et al., 2014).

The sizing of the number of measurements has been performed in several perennial crops, such as; acerola (LOPES et al., 2001), guava (DEGENHARDT et al., 2002), araçá and pitanga (DANNER et al., 2010), peach (BRUNA et al., 2012), sweet orange (NEGREIROS et al., 2014), banana (LESSA et al., 2014) and Urochloa brizantha (TORRES et al, 2015). In general, the authors of these studies observed that the multivariate methods are more accurate, compared to univariate method, however, they recommend that researches are made with other crops before the generalizing these results. Thus, this research aimed to determine the minimum number of cuts for selection with greater efficiency and reliability and to phenotypic stabilization of $P$. maximum cultivars.

\section{MATERIAL AND METHODS}

The experiment was conducted at the State University of Mato Grosso do Sul in the Fitotecnia Department, located in the Cerrado biome (Brazilian Savanna), situated in the municipality of Aquidauana, MS, Brazil $\left(20^{\circ} 27^{\prime} \mathrm{S}, 55^{\circ} 40^{\prime} \mathrm{W}\right.$, with an average altitude of $170 \mathrm{~m}$ ). The soil of the area was classified as Alfissol dystrophic, with the following chemistry characteristics in $0-0.20 \mathrm{~m}$ layer: $\mathrm{pH}$ $\left(\mathrm{H}_{2} \mathrm{O}\right)=6.20$; Organic matter $\left(\mathrm{g} \mathrm{dm}^{-3}\right)=19.74$; $\mathrm{H}+\mathrm{Al}\left(\mathrm{cmol}_{\mathrm{c}} \mathrm{dm}^{-3}\right)=5.51 ; \mathrm{Al}$ exchangeable $\left(\mathrm{cmol}_{\mathrm{c}}\right.$ $\left.\mathrm{dm}^{-3}\right)=0.00 ; \mathrm{Ca}+\mathrm{Mg}\left(\mathrm{cmol}_{\mathrm{c}} \mathrm{dm}^{-3}\right)=4.31 ; \mathrm{P}(\mathrm{mg}$ $\left.\mathrm{dm}^{-3}\right)=41.30 ; \mathrm{K}\left(\mathrm{cmol}_{\mathrm{c}} \mathrm{dm}^{-3}\right)=0.20$; Sum of bases $\left(\mathrm{cmol}_{\mathrm{c}} \mathrm{dm}^{-3}\right)=4.51 ;$ CEC $\left(\mathrm{cmol}_{\mathrm{c}} \mathrm{dm}^{-3}\right)=10.02 ; \mathrm{V}$ $(\%)=45.00 ; \mathrm{m}(\%)=0.00$. The climate of the region, according to the classification described by Köppen-Geiger is of type Aw (Tropical Savanna) with average annual precipitation of $1,200 \mathrm{~mm}$ and maximum and minimum temperatures of 26.2 and $28.4^{\circ} \mathrm{C}$, respectively.

It was used three cultivars of $P$. maximum (Massai, Mombaça and Tanzânia). We sowed the grass seeds in August 2011, using the proportion of $10 \mathrm{~kg} \mathrm{ha}^{-1}$ of seeds, being each cultivar sowing in an area of $10 \mathrm{~m}^{2}$. From September 2011 to August 2012 were performed six harvests manually to establish $10 \mathrm{~cm}$ of height (from the floor). The first harvest was realized in October 2011, and the other harvests were performed at 60 days of regrowth. In each sample were harvests plants contained in $1 \mathrm{~m}^{2}$ of each experimental unit, being performed to separate the leaves and stems.
The plants were placed in perforated paper bags and taken to the oven with circulation and renewal of air to $65^{\circ} \mathrm{C}$ by 72 hours. Subsequently, the following evaluations were made: dry mass of leaves, dry mass of stems and total dry mass (DML, DMS and TDM, respectively). To estimate the coefficient of repeatability (r) of each trait evaluated, four methods were used: analyses of variance (ANOVA), principal components analyses (PCA) based on the phenotypic variance and covariance matrices and structural analyses (SA) as described by Cruz et al. (2014).

To estimate the coefficient of repeatability by the ANOVA method, the statistical model with two factors of variation was used: $Y_{i j}=\mu+g_{i}+a_{i j}+e_{i j}$, in which $\mu=$ overall mean; $g_{i}=$ random effect of the $i$-th cultivar under the influence of the permanent environment; $a_{i j}=$ fixed effect of the temporary environment associated with the $j$-th measure on the $i$-th cultivar; $\mathrm{e}_{\mathrm{ij}}=$ temporary environmental effect associated with the $\mathrm{j}$-th measurement on the $\mathrm{i}$-th genotype.

For this model, the coefficient of repeatability was estimated by: $r=\frac{\operatorname{Cov}\left(y_{i j}, Y_{i j}\right)}{\sqrt{\operatorname{Var} y_{i j} \times \operatorname{Var} Y_{i j}}}=\frac{\sigma_{g}^{2}+\sigma_{E S}^{2}}{\sigma_{g}^{2}+\sigma_{E S}^{2}+\sigma_{E G}^{2}}, \quad$ in which $\sigma_{\mathrm{g}}^{2}$ is the covariance between repeated measurements in each cultivar; $\sigma_{\mathrm{ES}}^{2}$ is the variance of the permanent environment; $\sigma_{\mathrm{EG}}^{2}$ is the variance of the general environment.

The coefficient of repeatability by PCA was estimated based on the correlations matrix and matrices of phenotypic variance and covariances. The method of correlation matrix was proposed by Abeywardena (1972) and is based on obtaining a correlation matrix among the repeated measures and posterior estimate of the normalized eigenvalues and eigenvectors. The coefficient of repeatability (r) was estimated by: $r=\frac{\hat{\lambda}_{1}-1}{\eta-1}$, in which $\hat{\lambda}_{1}$ is the eigenvalue of the correlation matrix associated with the eigenvector whose elements have the same sign and similar magnitude and $\eta$ is the number of measures.

The coefficient of repeatability PCA was estimated based on the phenotypic variance and covariance matrix was obtained by: $r=\rho \frac{\hat{\lambda}_{1}-\sigma_{r}^{2}}{\sigma_{r}^{2} \times(\eta-1)}$ in which $\hat{\lambda}_{1}$ is the eigenvalue of 
phenotypic variance and covariance matrix associated with the eigenvector whose elements have the same sign and similar magnitude, $\sigma_{\mathrm{r}}^{2}=\sigma_{\mathrm{g}}^{2}+\sigma_{\mathrm{e}}^{2}$ is the variance of the character $\mathrm{Y}$, in which $\sigma_{\mathrm{g}}^{2}$ is the covariance between repeated measurements in each cultivar; and $\sigma_{\mathrm{e}}^{2}$ is the variance of the environment (CRUZ et al, 2014).

The SA method was based only on the interclass correlations and was estimated by: $r=\frac{\hat{\alpha} \mathrm{R} \hat{\alpha}-1}{\eta-1}$ in which $\hat{\lambda}_{1}=\hat{\alpha} \mathrm{R} \hat{\alpha}$ eigenvalue of the interclass correlation matrix associated with the eigenvector whose elements have the same sign and similar magnitude and $\hat{\alpha}$ is the eigenvector associated to $\hat{\lambda}_{1}$, so that $\hat{\alpha} \hat{\alpha}=1$ (CRUZ et al, 2014).

For each trait, the minimum number of measures necessary (n) to obtain efficiency in the selection process, based on pre-determined determination coefficients $\left(\mathrm{R}^{2}\right)(80,85,90,95$ and $99 \%)$, was estimated by $\mathrm{n}=\frac{\mathrm{R}^{2} \times(1-\mathrm{r})}{\left(1-\mathrm{R}^{2}\right) \times \mathrm{r}}(\mathrm{CRUZ}$ et al, 2014).
The phenotypic stability of the traits was evaluated using the principal components methods obtained from the interclass correlation matrix for the successive measures, considering 2, 3, 4, 5 and 6 until all $n$ evaluations were done. Therefore, $n-1$ analyses were done on two successive measures; n-2 analyses were done on three successive evaluations until reaching six measures (MARTUSCELLO et al., 2007). All analyses were done with use of the computer software GENES (CRUZ et al., 2013)

\section{RESULTS AND DISCUSSION}

The variable DML obtained the lowest scores of $\mathrm{r}$ and $\mathrm{R}^{2}$, when compared to the other evaluated variables (Table 1), indicating that, in general, this trait requires a greater number of cuts for evaluation. In the selection process of new forage, the trait DML, fundamental in animal nutrition is essential, because the leaves have a higher digestibility in relation to DMS. Selection based on this trait tends to make the genetic breeding process more efficient, particularly in the final stage, when the evaluation of weight gain is the main indicator of use potential of the plant (MARTUSCELLO et al, 2007).

Table 1. Coefficients of repeatability ( $r)$ and determination ( $R$, in \%) estimated for dry mass of leaves, dry mass of stems and total dry mass (DML, DMS and TDM, respectively) estimated by different methods in $P$. maximum.

\begin{tabular}{ccccccc}
\hline \multirow{2}{*}{ Method } & \multicolumn{2}{c}{ DML } & \multicolumn{2}{c}{ DMS } & \multicolumn{2}{c}{ TDM } \\
& $\mathrm{r}$ & $\mathrm{R}^{\mathbf{2}}$ & $\mathrm{r}$ & $\mathrm{R}^{\mathbf{2}}$ & $\mathrm{r}$ & $\mathrm{R}^{\mathbf{2}}$ \\
\hline ANOVA & 0.65 & 92 & 0.52 & 87 & 0.73 & 94 \\
PCA (covariance) & 0.72 & 94 & 0.86 & 97 & 0.87 & 98 \\
PCA (correlation) & 0.72 & 94 & 0.78 & 96 & 0.80 & 96 \\
SA (correlation) & 0.70 & 93 & 0.46 & 84 & 0.79 & 96 \\
\hline
\end{tabular}

ANOVA: analyses of variance; PCA: principal components analyses based on the phenotypic variance and covariance matrices; SA: structural analyses.

The estimates of $r$ for the evaluated variables, in general, can be considered high and indicate the reliability in the identification of the best genotypes, considering the six assessments used. Results in similar magnitudes were obtained by Cargnelutti Filho et al. (2004) and Martuscello et al. (2007) when assessed the repeatability of agronomic traits in $P$. maximum.

The limits $r \geq 0.40$ and $R^{2} \geq 0.75$ are considered reliable by Bergo et al. (2013) and Oliveira and Moura (2010), respectively. As the $\mathrm{R}^{2}$ expressed the accuracy in predicting the true value of the individual, reinforcing the hypothesis that six cuts are sufficient to provide high reliability in the prediction of different genotypes behavior.
When a trait has high $\mathrm{R}$, there is indication of little gain in accuracy with the increase in number of repeated measurements. However, when these scores are low, it is necessary a large number of cuts for achieving satisfactory determination value. Thus, with the increase in number of cuts for the assessed traits, decreases the temporary variance caused by the environment and, of course reduces the phenotypic variance, improving the accuracy of r. It is noteworthy that, when the temporary environmental variance is low and $r$ is high, the increase in the number of cuts will add little to improve of the individual genotypic value inference. However, if the $r$ value is low, increasing the number of cuts there will be gain increase (MARTUSCELLO et al, 2007; CRUZ et al., 2014). 
Estimates of the number of cuts required, obtained for the three traits evaluated by ANOVA method, were higher than those obtained by other methods evaluated (Table 2). By the method of ACP (based on matrix of covariance or correlation), these estimates were always lower than those obtained by other methods, corroborating the results obtained by Cargnelutti Filho et al. (2004) and Martuscello et al. (2007) for P. maximum.

Table 2. Number of harvests required to evaluate dry mass of leaves, dry mass of stems and total dry mass (DML, DMS and TDM, respectively), estimated by different methods and associated to different determination coefficients $\left(\mathrm{R}^{2}\right)$ in P. maximum.

\begin{tabular}{|c|c|c|c|c|}
\hline $\mathrm{R}^{2}(\%)$ & ANOVA & PCA (covariance) & PCA (correlation) & SA (correlation) \\
\hline & \multicolumn{4}{|c|}{ DML } \\
\hline 80 & 2 & 2 & 2 & 2 \\
\hline 85 & 3 & 2 & 2 & 2 \\
\hline 90 & 5 & 3 & 3 & 4 \\
\hline 95 & 10 & 7 & 7 & 8 \\
\hline 99 & 53 & 38 & 38 & 42 \\
\hline & \multicolumn{4}{|c|}{ DMS } \\
\hline 80 & 4 & 1 & 1 & 5 \\
\hline 85 & 5 & 1 & 2 & 6 \\
\hline 90 & 8 & 1 & 2 & 10 \\
\hline 95 & 17 & 3 & 5 & 22 \\
\hline 99 & 91 & 16 & 27 & 145 \\
\hline & \multicolumn{4}{|c|}{ TDM } \\
\hline 80 & 1 & 1 & 1 & 1 \\
\hline 85 & 2 & 1 & 1 & 2 \\
\hline 90 & 3 & 1 & 2 & 2 \\
\hline 95 & 7 & 3 & 5 & 5 \\
\hline 99 & 87 & 15 & 24 & 26 \\
\hline
\end{tabular}

According to Abeywardena (1972), ACP method allows estimate $r$ more efficiently in situations when the genotypes have cyclical behavior in relation to the trait studied, for be based on the covariance matrix among genotypes obtained for each pair of measurements, explaining the results obtained in this study. This method was also considered suitable for other perennial crops, like coconut (SIQUEIRA, 1982), rubber tree (VASCONCELLOS et al., 1985), pine (CORNACCHIA et al., 1995), cupuaçu tree (COSTA et al., 1997), alfalfa (FERREIRA et al., 1999), cacao (DIAS \& KAGEYAMA, 1998), acai palm (OLIVEIRA \& FERNANDES, 2001), acerola (LOPES et al., 2001), guava (DEGENHARDT et al., 2002), Napier grass (SHIMOYA et al., 2002), araçá and pitanga (DANNER et al., 2010), peach (BRUNA et al., 2012), sweet orange (NEGREIROS et al., 2014) and banana (LESSA et al., 2014).

The increase in the accuracy with regarding to prediction of the true value of the evaluations $\left(\mathrm{R}^{2}>85 \%\right)$, in all used methods, resulted in considerable increase in the number of cuts necessary for all variables. These data suggest that the attempt to increase accuracy further than $85 \%$ would require a significant increase in time and work force available to each evaluation, becoming the process expensive.

The use of stabilized genotypes in obtaining estimates of $r$ is essential. In some cases, it is possible for a trait to be governed by distinct gene sets and the genes are more or less active according to the individual development state. Thus, the inclusion of evaluations in early stage where there is no full expression of the plant's genetic potential, or in later evaluations where the forage shows a certain senescence degree, the repeatability may be underestimated. If the genotype at which the measurements are taken is not stabilized, the variation within individuals will include substantial proportion of the variance of the interaction genotype $\times$ temporary environment and the increase in the number of measurements. This may reduce the variation within individuals may not be advantageous, because the additional variance may be sufficient for neutralizing the reduction of the component (MARTUSCELLO et al, 2007).

For the trait DML, the lowest coefficient of repeatability was obtained when were correlated the cuts $1 \times 2,2 \times 3$ and $1 \times 2 \times 3$ (Table 3 ), which was probably due to the fact that, in the first three cuts, the genotypes not were stabilized. In addition, 
stabilization may have undergone the effect of the cultivars flowering time, since in the flowering occurs greater accumulation of stem and, consequently, direct effect of this accumulation on the production of the evaluated variables
TORRES, F. E. et al.

(MARTUSCELLO et al, 2007). In general, although the regularity in behavior of the individuals in the cuts 1, 2 and 3, the inclusion of data from these cuts tends to decrease, suggesting that the exclusion of the first three cuts data in future evaluations.

Table 3. Number of cuts and coefficients of repeatability ( $r$ ) and determination ( $R$, in \%) obtained by phenotypic stability using the method of principal components analysis from the correlation matrix for dry mass of leaves, dry mass of stems and total dry mass (DML, DMS and DMT, respectively) in P. maximum.

\begin{tabular}{cccccccc}
\hline Cut & \multirow{2}{*}{ Number of harvests } & \multicolumn{2}{c}{ DML } & \multicolumn{2}{c}{ DMS } & \multicolumn{2}{c}{ TDM } \\
& & $\mathrm{r}$ & $\mathrm{R}^{2}$ & $\mathrm{r}$ & $\mathrm{R}^{\mathbf{2}}$ & $\mathrm{r}$ & $\mathrm{R}^{\mathbf{2}}$ \\
\hline 1 and 2 & 2 & 0.66 & 88 & 0.74 & 95 & 0.73 & 84 \\
2 and 3 & 2 & 0.72 & 94 & 0.72 & 94 & 0.72 & 94 \\
3 and 4 & 2 & 0.77 & 87 & 0.74 & 95 & 0.12 & 22 \\
4 and 5 & 2 & 0.99 & 99 & 0.84 & 91 & 0.74 & 95 \\
5 and 6 & 2 & 0.99 & 99 & 0.74 & 95 & 0.84 & 91 \\
1,2 and 3 & 3 & 0.52 & 76 & 0.59 & 81 & 0.39 & 65 \\
2, 3 and 4 & 3 & 0.58 & 81 & 0.72 & 94 & 0.44 & 70 \\
3, 4 and 5 & 3 & 0.87 & 95 & 0.72 & 94 & 0.53 & 77 \\
4,5 and 6 & 3 & 0.99 & 99 & 0.74 & 95 & 0.72 & 94 \\
$1,2,3$ and 4 & 4 & 0.62 & 86 & 0.71 & 91 & 0.47 & 78 \\
$2,3,4$ and 5 & 4 & 0.68 & 90 & 0.69 & 90 & 0.57 & 84 \\
$3,4,5$ and 6 & 0.72 & 94 & 0.72 & 94 & 0.47 & 78 \\
$1,2,3,4$ and 5 & 4 & 0.69 & 92 & 0.78 & 95 & 0.58 & 88 \\
$2,3,4,5$ and 6 & 5 & 0.70 & 92 & 0.74 & 93 & 0.58 & 88 \\
$1,2,3,4,5$ and 6 & 5 & 0.72 & 94 & 0.78 & 95 & 0.61 & 90 \\
\hline
\end{tabular}

\section{CONCLUSIONS}

Seven harvests are necessary to discriminate with $85 \%$ accuracy in $P$. maximum cultivars based on the traits dry mass of leaves, dry mass of stems and total dry mass.
The exclusion of the first three cuts promotes increase in coefficients of repeatability and determination due to forage production stabilization of $P$. maximum cultivars.

RESUMO: A avaliação do coeficiente de repetibilidade permite verificar se a superioridade ou a inferioridade inicial de um indivíduo mantém-se ao longo das medições, sendo importante para programas de melhoramento genético com forrageiras. Assim, esta pesquisa teve como objetivo determinar o número mínimo de cortes para a seleção com maior eficiência e confiabilidade e para a estabilização fenotípica de cultivares de $P$. maximum. O experimento foi conduzido durante os meses de setembro de 2011 a outubro de 2012 na Universidade Estadual de Mato Grosso do Sul. Foram utilizadas três cultivares de P. maximum (Massai, Mombaça e Tanzânia) para avaliação da massa seca das folhas, colmos e total em seis cortes. A partir de destes cortes, estimou-se o coeficiente de repetibilidade pelos métodos da ANOVA, componentes principais (matriz de correlação e covariância) e Análise estrutural, bem como o número de cortes necessários com base em coeficientes de determinação pré-estabelecidos $(0,80,0,85,0,90,0,95$ e 0,99$)$. Sete cortes são necessárias para discriminar com precisão de $85 \%$ cultivares de $P$. maximum com base nos caracteres massa seca de folhas, colmos e total. A exclusão das três primeiras colheitas promove aumento da repetibilidade e determinação coeficientes devido à estabilização da produção de forragem de cultivares de P. maximum.

PALAVRAS-CHAVE: Confiabilidade. Precisão experimental. Repetibilidade.

\section{REFERENCES}

ABEYWARDENA, V. An application of principal component analysis in genetics. Journal Genetics, Sadashivanagar, v. 16, p. 27, 1972. 
BERGO, C. L.; NEGREIROS, J. R. S.; MIQUELONI, D. P.; LUNZ, A. M. P. Estimativa de repetibilidade de caracteres de produção em pupunheiras para palmito da raça Putumayo. Revista Brasileira de Fruticultura, Jaboticabal, v. 35, p. 829-836, 2013.

BRUNA, E. D.; MORETO, A. L.; DALBÓ, M. A. Uso do coeficiente de repetibilidade na seleção de clones de pessegueiro para o Litoral Sul de Santa Catariana. Revista Brasileira de Fruticultura, Jaboticabal, v. 34, p. 206-215, 2012.

CARGNELUTTI FILHO, A.; CASTILHO, Z. M. S.; STORCK.; SAVIAN, J. F. Análise de repetibilidade de caracteres forrageiros de genótipos de Panicum maximum, avaliados com e sem restrição solar. Ciência Rural, Santa Maria, v. 34, p. 723-729, 2004. http://dx.doi.org/10.1590/S0103-84782004000300011

CORNACCHIA, G.; CRUZ, C. D.; PIRES, I. E. Estimativa do coeficiente de repetibilidade para características fenotípicas de procedências de Pinus tecunumanii (Schw.) Eguiluz \& Perry e Pinus caribaea var. hondurensis Barret \& Golfari. Revista Árvore, Viçosa, v. 19, n. 3, p. 333-345, 1995.

COSTA, J. G.; LEDO, A. S; OLIVEIRA, M. N. Estimativas de repetibilidade de características de frutos de cupuaçuzeiro no Estado do Acre. Revista Brasileira de Fruticultura, Jaboticabal, v. 19, n. 3, p. 313-318, 1997.

CRUZ, C. D. GENES - a software package for analysis in experimental statistics and quantitative genetics. Acta Scientiarum Agronomy, Maringá, v. 35, p. 271-276, 2013. http://dx.doi.org/10.4025/actasciagron.v35i3.21251

CRUZ, C. D.; CARNEIRO, P. C. S.; REGAZZI, A. J. Modelos biométricos aplicados ao melhoramento genético. 3.ed. Viçosa: Editora UFV, 2014. 668p.

DANNER, M. A.; RASEIRA, M. C. B.; SASSO, S. A. Z.; CITADIN, I.; SCARIOT, S. Repetibilidade de caracteres de fruto em araçazeiro e pitangueira. Ciência Rural, Santa Maria, v. 40, p. 2086-2091, 2010. http://dx.doi.org/10.1590/S0103-84782010005000163

DEGENHARDT, J.; DUCROQUET, J. P.; REIS, M. S.; GUERRA, M. P.; NODARI, R. O. Efeito de anos e determinação do coeficiente de repetibilidade de características de frutos de goiabeira-serrana. Pesquisa Agropecuária Brasileira, Brasília, v. 37, p. 1285-1293, 2002. http://dx.doi.org/10.1590/S0100204X2002000900012

DIAS, L. A. S.; KAGEYAMA, P. Y. Repeatibility and minimum harvest period of cacao (Theobroma cacao L.) jn southern Bahia. Euphytica, Dordrecht, v. 102, p. 29-35, 1998. http://dx.doi.org/10.1023/A:1018373211196

FERREIRA, R. P.; BOTREL, M. A.; PEREIRA, A. V.; CRUZ, C. D. Avaliação de cultivares de alfafa e estimativas de repetibilidade de caracteres forrageiros. Pesquisa Agropecuária Brasileira, Brasília, v. 34, n. 6, p. 995-1002, 1999. http://dx.doi.org/10.1590/S0100-204X1999000600010

LESSA, L. S.; LEDO, C. A. S.; AMORIN, E. P.; SILVA, S. O. Estimativas de repetibilidade de híbridos diploides (AA) de bananeira. Pesquisa Agropecuária Brasileira, v. 49, n. 2, p. 109-117, 2014. http://dx.doi.org/10.1590/S0100-204X2014000200005

LOPES, R.; BRUCKNER, C. H.; CRUZ, C. D.; LOPES, M. T. G.; FREITAS, G. B. Repetibilidade de características do fruto de aceroleira. Pesquisa Agropecuária Brasileira, Brasília, v. 36, p. 507-513, 2001. http://dx.doi.org/10.1590/S0100-204X2001000300015

MARTUSCELlO, J. A.; JANK, L.; FONSECA, D. M.; CRUZ, C. D.; CUNHA, D. N. F. V. Repetibilidade de caracteres agronômicos em Panicum maximum Jacq. Revista Brasileira de Zootecnia, Viçosa, v. 36, p. 19751981, 2007. 
NEGREIROS, J. R. S.; ANDRADE NETO, R. C.; MIQUELONI, D. P.; LESSA, L. S. Estimativa de repetibilidade para caracteres de qualidade de frutos de laranjeira-doce. Pesquisa Agropecuária Brasileira, Brasília, v. 49, n. 1, p. 40-48, 2014. http://dx.doi.org/10.1590/S0100-204X2014000100006

NEGREIROS, J. R. S.; SARAIVA, L. L.; OLIVEIRA, T. K.; ÁLVARES, V. S.; RONCATTO, G. Estimativas de repetibilidade de caracteres de produção em laranjeiras - doces no Acre. Pesquisa Agropecuária Brasileira, Brasília, v. 43, p. 1763-1768, 2008. http://dx.doi.org/10.1590/S0100-204X2008001200017

OLIVEIRA, M. S. P.; MOURA, E. F. Repetibilidade e número mínimo de medições para caracteres de cacho de bacabi (Oenocarpus mapora). Revista Brasileira de Fruticultura, Jaboticabal, v. 32, p. 1173-1179, 2010.

OLIVEIRA, E. P.; SILVEIRA, L. P. O.; TEODORO, P. E.; ASCOLI, F. G.; TORRES, F. E. Efeito do sombreamento e do incrustamento de sementes sobre o desenvolvimento inicial de cultivares de Panicum maximum Jacq. Bioscience Journal, Uberlândia, v. 30, p. 1682-1691, 2014.

OLIVEIRA M. S. P.; FERNANDES G. L. C. Repetibilidade de caracteres do cacho de açaizeiro nas condições de Belém-PA. Revista Brasileira Fruticultura, Jaboticabal, v. 23, n. 3, p. 613-616, 2001.

TORRES, F. E.; OLIVEIRA, E. P.; TEODORO, P. E.; SILVEIRA, M. V.; RIBEIRO, L. P.; SILVEIRA, L. P. O. Produção de forragem de cultivares de Panicum maximum submetidas a diferentes estações de cultivo e tipos de sementes. Revista de Ciências Agrárias, Lisboa, v. 36, p. 435-440, 2013.

TORRES, F. E.; VALLE, C. B.; LEMPP, B.; TEODORO, P. E.; SANTOS, A.; SILVA JUNIOR, A. C. Minimum number of measurements for accurate evaluation of qualitative traits in Urochloa brizantha. Journal of Agronomy, Nova York, v. 14, p. 180-184, 2015a. http://dx.doi.org/10.3923/ja.2015.180.184

TORRES, F. E.; SILVA FILHO, N. M.; TEODORO, P. E.; RIBEIRO, L. P.; NASCIMENTO, J. N.; FERREIRA, R. S. Crescimento e produção de forragem de cultivares de Panicum maximum em função do tipo de semente. Global Science and Technology, Goiânia, v. 08, p. 40-46, 2015 b.

SHIMOYA, A.; PEREIRA, A. V.; FERREIRA, R. P; CRUZ, C. D.; CARNEIRO, P. C. S. Repetibilidade de características forrageiras do capim-elefante. Scientia Agricola, Piracicaba, v. 59, n. 2, p. 227-234, 2002. http://dx.doi.org/10.1590/S0103-90162002000200004

SIQUEIRA, E. R. Coeficiente de repetibilidade da produção de frutos do coqueiro comum. Pesquisa Agropecuária Brasileira, Brasília, v. 17, n. 4, p. 573-574, 1982.

VASCONCELlOS, M. E. C.; GOÇALVES, P. S.; PAIVA, J. R.; VALOIS, A. C. C. Métodos de estimação do coeficiente de repetibilidade no melhoramento da seringueira. Pesquisa Agropecuária Brasileira, Brasília, v. 20, n. 4, p. 433-437, 1985. 